\title{
ARE BARK BEETLES RESPONSIBLE FOR DROUGHTS IN THE ŠUMAVA MTS.? A MINI-REVIEW
}

\author{
KAROLÍNA BÍLÁ* \\ Department of Biodiversity Research, Global Change Research Institute CAS, Bělidla 986/4a, 60300 Brno, Czech Republic \\ *Corresponding author: kcerna@volny.cz
}

\begin{abstract}
We attempt here to review recent studies focusing on droughts and hydrology in the Šumava Mts. The main question is can bark beetles affect water regimes in forest and what kind of measures might be taken - if any - to prevent bark beetle attacks. We compared results for natural forest, clear-cuts in managed forest and dead forest killed by a bark beetle attack. As expected, there was more water and a lower air temperature above the soil surface in natural forest. Dead trees shade undergrowth and so moderate temperature fluctuations. The conditions in clear-cuts are the worst for natural forest regeneration. There are no significant changes in the water cycle in catchment areas affected by bark beetle infections. However, it is predicted there is likely to be a slow decline in the amount of water due to a local change in climate, i.e. air temperature increase and precipitation decrease. It is concluded that droughts might occur more often and independently of bark beetle outbreaks in the future.
\end{abstract}

Keywords: bark beetle, climate change, forest management, hydrological cycle

\section{Introduction}

Bark beetles are an inseparable part of the forest ecosystems in the Šumava National Park (NP). These tiny beetles recently became a hot topic in scientific discussions and a tool of political decisions on forest management in the national park. However, scientific and political views are often contradictory (Kindlmann and Křenová 2016).

In 2015, there were extensive droughts in Western and Central Europe including the Czech Republic (CZ). The annual precipitation was only $500 \mathrm{~mm}$, measured from November 2014 to October 2015. It was the lowest rainfall for the last 55 years (similarly there was a low rainfall in 1973). This dry weather was preceded by a below-average hydrological year (2014) in Bohemia. The deficiency in rainfall continued for two years and as a consequence there was a negative moisture balance, soil drought and a ground water deficit (Bečka and Beudert 2016). The levels of most streams were lower than normal and some ran dry. The Šumava NP also experienced one of the driest years in the last half-century (Bečka and Beudert 2016).

This study focuses on current problems with bark beetles and especially their effect on the hydrological situation (Fig. 1) in the Šumava NP. We attempt to compare natural forest, managed forest and dead forest (after bark beetle attack) in relation to different aspects of the water and temperature regimes in the area studied.

Photographs of the three forest types compared are shown in Figs. 2-4. Fig. 2 shows a green forest without signs of damage in the unmanaged zone, Fig. 3 is a "grey" forest about 10 years after a bark beetle attack, in which natural regeneration of the forest is occurring, and Fig. 4 is of a clearing aimed to stop bark beetles spreading.

\section{WATER REGIME}

\section{Precipitation and Water Vapour Circulation in the Atmosphere}

\section{Does the amount of precipitation affect the cover or type of vegetation?}

A deforested landscape is much warmer and receives less rainfall than a forested landscape. But is it likely that a bark beetle outbreak and resultant dead forest affects the climate? Pokorný and Hesslerová (2011) and Makarieva and Gorshkov (2007) describe a biotic pump in which water vapour condenses above cold tree crowns producing fog, which falls as rain and so retains moisture in the ecosystem. At the same time, air pressure decreases and air with water from surrounding areas is drawn into the area above the forest. If such a pump works in this way, the amount of rain falling on dead and dry forests would decrease significantly. The question is, is this type of forest dryer? When we compare dead and green undamaged forests the dead forest may be dryer, at least

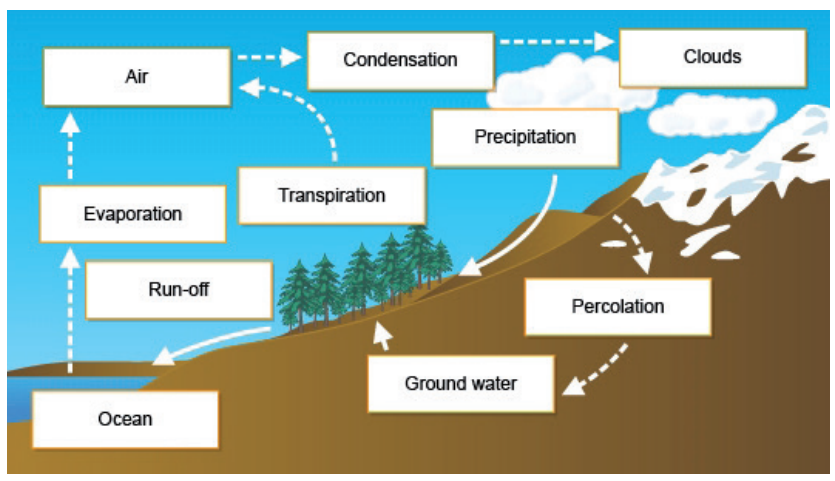

Fig. 1 The hydrological cycle (source: www.bbc.co.uk) 


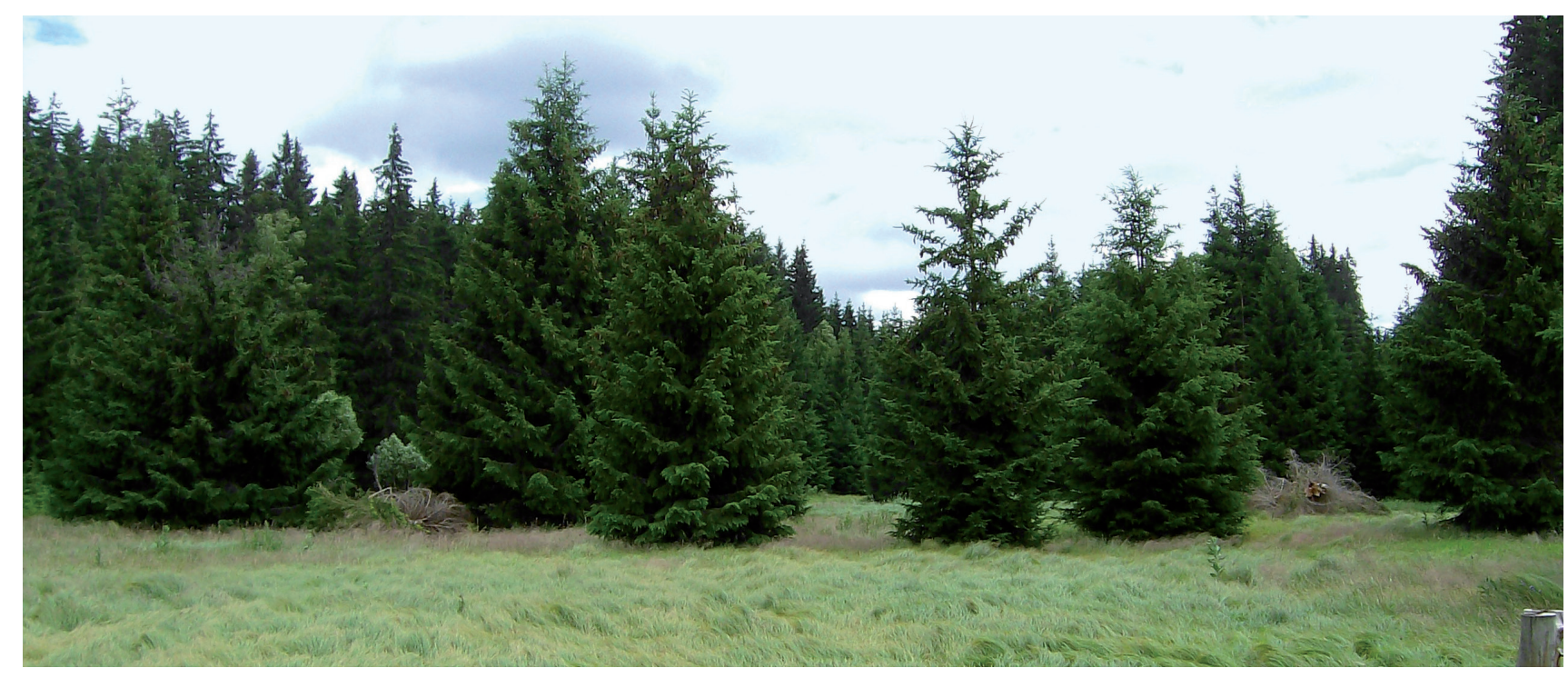

Fig. 2 Green forest without signs of damage in the unmanaged zone (photo: P. Kindlmann).

in the initial phases after the attack, before the massive re-growth of new trees occurs. But what about forest that has been clear cut to stop a bark beetle attack?

It is already known that less rain water drains away in rivers in forested ecosystems than in grassland or drained fields (Gutierrez 2016). The question is how much of the rainfall drains away from dead forest with rich green undergrowth, however.

\section{Surface Water}

\section{Does surface run-off increase in a catchment area where the forest is damaged by bark beetles?}

One of the largest areas with dead trees due to bark beetle attack is located in the Modravský potok catch- ment area in the surroundings of Březník, which is in an unmanaged forest zone. In this area it is possible to determine whether floods and droughts are more likely where the forest is dead. The catchment area of Modravský potok includes three areas: one covered with green forest, one with dead forest and one with clearings and other land. The run-off from these areas was measured using a limnigraph above Modrava village and the amount of precipitation was obtained from a nearby meteorological station (Filipova Hut'). The data for this study was collected from 1971-2015. Changes in the precipitation /run-off ratio would indicate that forest clearings have an effect. However, the annual run-off of the Modravský potok did not change (Hruška et al. 2016). The increase in run-off in March and April could have been caused by several factors (Hais et al. 2006). This could be partly due

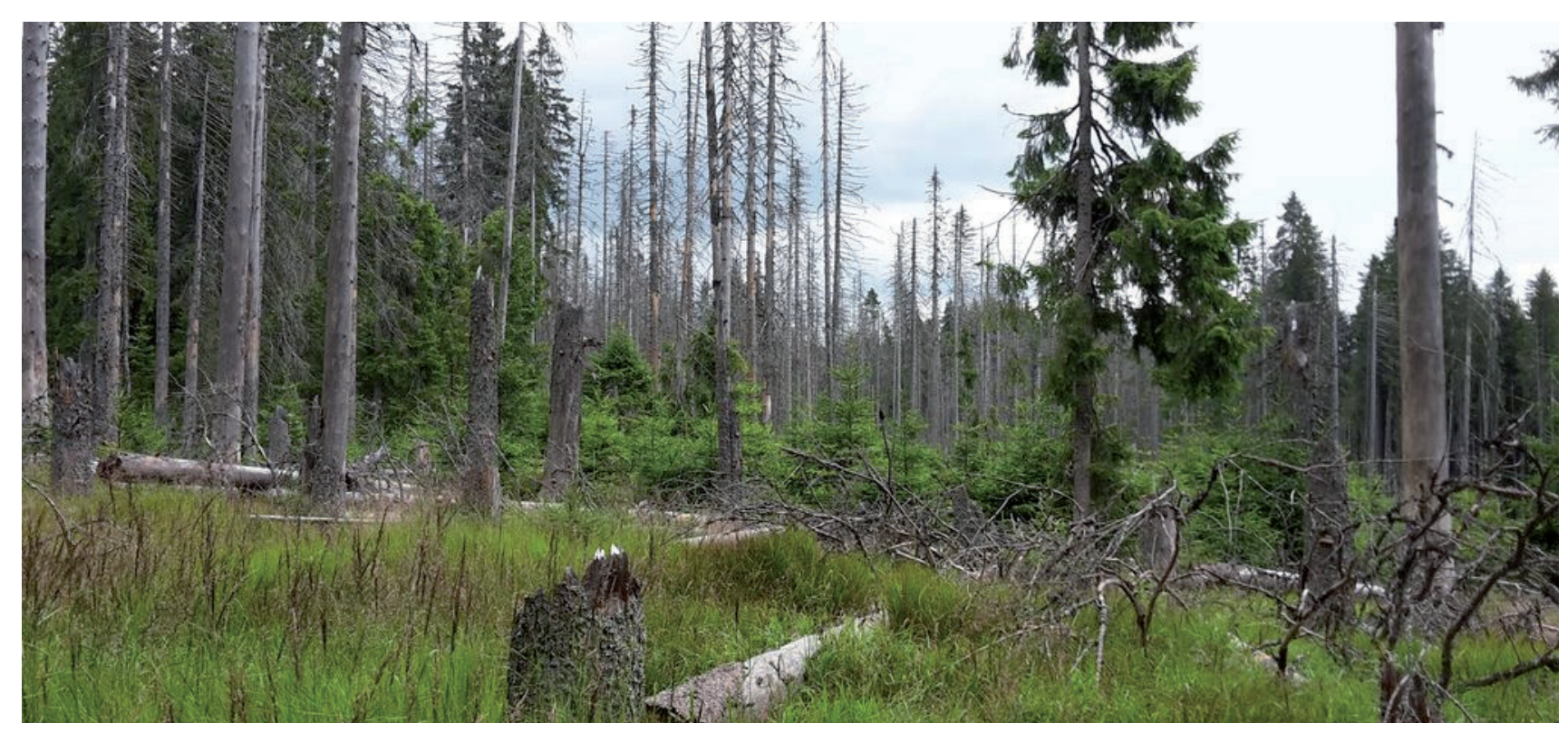

Fig. 3 "Grey" forest about 10 years after the bark beetle attack, in which natural regeneration of the forest is occurring (photo: K. Bílá). 


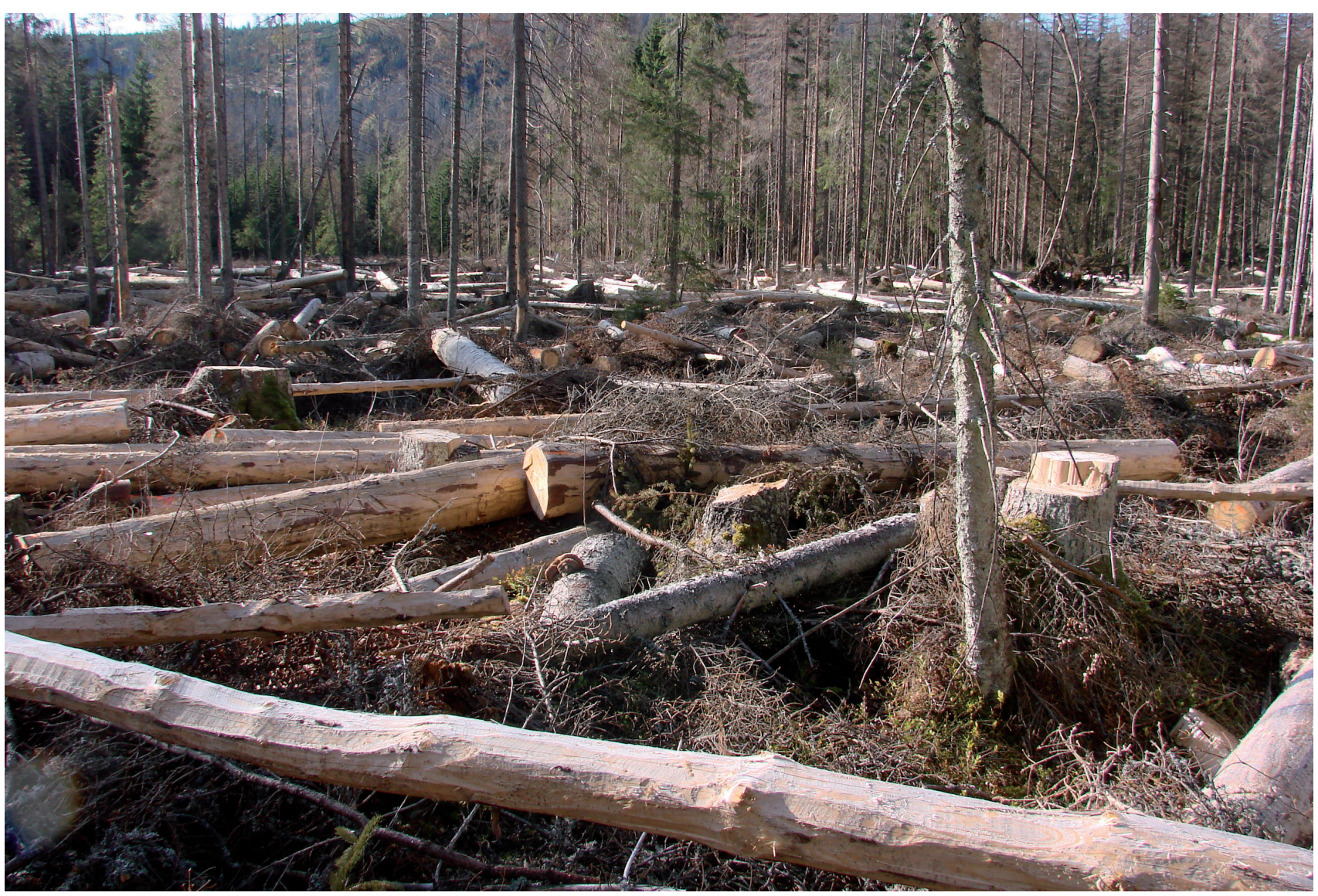

Fig. 4 Clear felling aimed at stopping the bark beetle from spreading (photo: P. Kindlmann).

to a change in the vegetation cover as snow in treeless landscapes or in forest without mature trees is not shaded and melts earlier. Furthermore, an evident air temperature increase causes an earlier snow melt in the Czech Republic and that's why the spring maximum run-offs shift from April/May to March/April in mountainous areas (Hruška et al. 2016).

Leaving dead trees at a site and its effect on water balance was studied by Bečka and Beudert (2016) in the natural unmanaged zone Roklan-Luzný from 1992-2013. During this period, precipitation did not change significantly. However, annual run-offs increased by about $15 \%$ with $146 \mathrm{l} / \mathrm{m}^{2}$ recorded in Forellenbach and $127 \mathrm{l} / \mathrm{m}^{2}$ in Große Ohe after $30 \%$ of the spruce died in this forest in 1999. Bečka and Beudert (2016) also compare these streams in these relatively small catchment areas with larger streams in the Bavarian Forest NP over the period 1978-2013. Although the annual precipitation remained the same over this period, they detected a decrease in annual run-offs in catchment areas that were disturbed to a lesser extent $(<36 \%)$. This is a consequence of an increased evaporation of water from the area studied and an increase in the summer temperature (see below). As indicated by previous research, the annual run-off from the most disturbed catchments in their long-term study, Vydra upper stream and Große Ohe (57\% and 58\%, respectively, of dead trees), remained unchanged.
One of the most serious negative effects that resulted from anthropogenic modifications of the river bed (artificial adjustments to the geometry of the river bed and stabilization of the banks or bottoms with non-indigenous material of different roughness) occurred in the lower parts of the stream in arable land with dense settlements. These might influence the flow rates in the upper streams where the forests subject to bark beetle attack are located. Thus, this data could be misinterpreted as indicating a negative effect of bark beetles on the run-off of surface water. The most modified catchment areas in the Šumava NP are: lower Blanice, middle and lower Otava and middle Ostružná, Spůlka and Volyňka.

\section{Groundwater}

\section{Can bark beetles affect groundwater?}

It is sometimes claimed that water quality in dead forests deteriorates, with $\mathrm{pH}$ increasing about $11 \%$ and decomposition of dead wood increasing nitrogen oxide $\left(\mathrm{NO}_{\mathrm{x}}\right)$ concentrations, which also negatively affect the drinking quality of groundwater (Vicena 2004). But scientific results based on field research show the opposite. Groundwater was enriched with nitrogen oxides during the bark beetle outbreak, but only temporarily. The increased $\mathrm{NO}_{\mathrm{x}}$ concentration was detected when $20 \%$ of 
the forest was dead and during the second bark beetle attack ( $60 \%$ of the trees in the forest were dead) there was no additional water enrichment with $\mathrm{NO}_{\mathrm{x}}$ as a slow decrease occurred. In the 10 years after the bark beetle outbreak, $\mathrm{NO}_{\mathrm{x}}$ concentrations decreased below the original value and groundwater quality even improved (Beudert et al. 2015).

Another factor associated with bark beetle outbreaks is a higher groundwater level. This is due to a temporary decrease in evapotranspiration from dead forest, which can result in muddy soil surface, unstable tree roots and uprooting of trees. This is why the use of heavy machinery when dealing with a bark beetle outbreak will mechanically disturb the soil surface and accelerate soil erosion (Kindlmann et al. 2012).

\section{Evapotranspiration}

Transpiration in dead forest is lower than in mature green forest but does it differ in amount when we consider the fast spontaneous regeneration in such forests?

Evapotranspiration rates depend on vegetation structure. Plants take up water from rain and ground water via their roots, which is transported from the roots to the leaves where it is transpired through stomata. Energy absorbed in water vapour is released when it condenses back into water, which happens in a cool environment after reaching the dew point. Therefore, evapotranspiration and condensation have a double effect on climate: a) plants cool down by transpiring, b) vapour condenses into water and this process releases heat, which warm the environment. Evapotranspiration can equalize local and day /night differences in temperature (Pokorný et al. 2011).

Bečka and Beudert (2016) record that in extensively disturbed spruce forest at Forellenbach and Große Ohe evapotranspiration decreased to about $120 \mathrm{l} / \mathrm{m}^{2}$ and $901 / \mathrm{m}^{2}$, respectively. Evapotranspiration in spruce forest in the Šmava NP is around $6001 / \mathrm{m}^{2}$. It consists of evaporation, the physical vaporization of precipitation on the surfaces of trees (cca 200-400 1/ $\mathrm{m}^{2}$ ) and transpiration, the release of water vapour from the needles via their stomata (cca 250-350 1// $\mathrm{m}^{2}$ ). Evapotranspiration decreases in infested woods, because a greater amount of the rain falls directly onto the soil because dead trees have a smaller surface area than live and green ones and dead trees do not respire water. More water soaks into the soil, groundwater supplies improve, stream flow increase and the annual run-off increases. Despite rainfall remaining constant over a long period, annual run-off decreased in the catchment areas where the extent of disturbance was low $(<36 \%)$. This clearly accounts for the increased evapotranspiration caused by a significant climate warming (see below). The higher evapotranspiration obviously accounts for the decrease in run-off in summer; however, summer precipitation increased in comparison to the past. As in the first study, the annual run-offs over a long period of time from the most disturbed catchment areas, upper Vydra and Große Ohe (57\% and 58\% dead trees, respectively), did not decline. It is also clear that evapotranspiration declined in areas that were extensively disturbed. A lower transpiration compensates for the increased evaporation due to climate change, but only temporarily. The fast regenerating vegetation quickly comes to use the same amount of water as untouched forests. However, water slowly disappears from these catchment areas because of local climate change.

To ensure the ecological functions of the forest, it is necessary to achieve the original evapotranspiration rate. In the case of the spontaneous regeneration in the unmanaged zone of the Šumava NP, almost 15\% of young trees had reached a height of $2 \mathrm{~m} 15$ years after the disturbance. In clear-cut areas fewer spruces regenerated spontaneously and trees were planted (often repeatedly) in order to reach the required number of trees. There are also differences in the herbaceous and moss floor regeneration and in the survival of indigenous forest species (for example Vaccinium myrtillus, Athyrium distentifolium, Dryopteris dilatata, Lycopodium annotinum, Soldanella montana). No change in numbers of these species were detected in dead forest but they often disappeared from clearings. Mosses responded to cutting even more dramatically as they were absent during the first year after the clear-cut. The artificially forest planted in the clearings will be more prone to disturbance in the future and is likely to have a shorter lifetime than spontaneously regenerated forest (Hubený and Čížková 2016).

\section{TEMPERATURE REGIME}

\section{Sunshine and Vegetation Cover}

\section{What is more favourable for forest regeneration, dead forest or clearings? Is there a difference in their vegetation cover and exposure to sun? And what is the role of dead standing trees?}

As mentioned above, vegetation structure is very important for evapotranspiration, which equalizes temperature fluctuations and disperses energy from the sun via its cooling effect. In dead forest herbaceous plants and mosses survive undamaged and it is assumed their evapotranspiration and dispersal of energy from the sun is greater than occurs in clearings. However, no field measures exist to prove this.

Next assumption is the positive effect of the shading by dead trees on the undergrowth even though these trees no longer transpire. Temperatures of the atmosphere and soil measured in green mature forest, dead forest and clearings are similar (Hais and Pokorný 2004; Tesař et al. 2004; Hais and Kučera 2008; Pokorný et al. 2011; Kindlmann et al. 2012). 


\section{Undergrowth and Air Temperature}

Are the temperature fluctuations in dead forest and clearings similar, comparable but different from those recorded in contrary to the green forest?

Tesař et al. (2004) measured temperature in the undergrowth $5 \mathrm{~cm}$ above the surface of the soil when midday temperature reached values above $30^{\circ} \mathrm{C}$. The midday temperature in the clearing fluctuated between $23-25^{\circ} \mathrm{C}$. In the green mature forest, it reached only $22^{\circ} \mathrm{C}$ as a consequence of the distance of the soil surface from the tree crown surface that cools by absorbing sunshine. These authors claim that dead forest is significantly less stable thermally than a clearing. Pokorný (2011) mentions an increase in the maximum temperature in dead forest by almost $20^{\circ} \mathrm{C}$, same as in the clearing. He predicts a water shortage because of the higher sunshine input and consequent drying out of the soil. Similar results are presented by Kindlmann et al. (2012), namely maximum air temperatures at a height of $2 \mathrm{~m}$ in green forest of $21.6^{\circ} \mathrm{C}$, dead forest of $34.6{ }^{\circ} \mathrm{C}$ and clearings of $39.7{ }^{\circ} \mathrm{C}$. These results confirm those of Hais and Kučera (2008) that the daily fluctuations in temperature recorded in dead spruce forests are higher in summer than in green forest however, temperatures in clearings are even higher than in dead spruce forests.

Lower temperatures recorded in the undergrowth in dead spruce forests (compared to clearings) are due to the shading effect of standing or lying dead tree trunks. Zielonka and Piatek (2004) also note that lying dead trunks accumulate water during their decomposition and so increase undergrowth moisture and evaporation, and as a consequence decrease undergrowth temperature. Temperature and air moisture can differ depending on climate, sensor location and stage of succession, nevertheless the assumption that clearings are more stable than dead forest, is wrong.

Bečka and Beudert (2016) also mention a statistically significant increase in summer temperatures since 1978 of about $2{ }^{\circ} \mathrm{C}$. Such a warming, especially from May till August, will result in higher evapotranspiration in the Šumava Mountains.

\section{Soil Temperature}

\section{As for air temperature it is interesting to ask if the fluctuations in soil temperature in dead forest and clearings are similar to those in green forest? $0 r$, if not, does the shade from the dead trees together with that of the undergrowth moderate the fluctuations in temperature?}

The daily fluctuations in temperatures recorded at the surface of the soil in clearings are noticeably greater than those recorded in green and dead forest. Hais and Kučera (2008) consider clearings to be unfavourable localities for forest regeneration just because of the extreme temperatures and dry conditions, soil impoverishment and ero- sion that limit the chance of tree seedlings overgrowing the herbaceous plants. Similar soil temperatures are cited by Kindlmann et al. (2012): green forest $21.5^{\circ} \mathrm{C}$, dead forest $27.4{ }^{\circ} \mathrm{C}$ and clearings $38.3^{\circ} \mathrm{C}$ (maximum temperatures). High soil temperatures in clearings could negatively affect soil revitalization and regeneration. That's why clear-cuts in mountainous spruce forests are considered to be the least suitable method of management aimed at reducing the incidence of bark beetle outbreaks in the Šumava NP.

\section{Conclusions}

The main aim of the Sumava NP is to have the highest possible proportion of the area covered by natural forests and to preserve the current hydrological situation. But forest age structure changes and diversifies over time and the current stage of decay (overlapping with the stage of regeneration) is prone to natural disturbances such as windstorms and attack by pests (Fig. 5). Old trees are extensively damaged over large areas instead of dying one by one. However, young seedlings quickly develop and a new generation of trees replace the dead trees. Such regeneration can occur within decades unlike in the zones that are managed by clear-cutting.

Unfortunately, droughts currently occur more frequently and independently of bark beetle outbreaks (Bečka and Beudert 2016). Water regime in the Šumava NP does not remain constant. However, this is not due to unmanaged zones with spontaneous forest regeneration but due to climate warming and changes in the distribu-

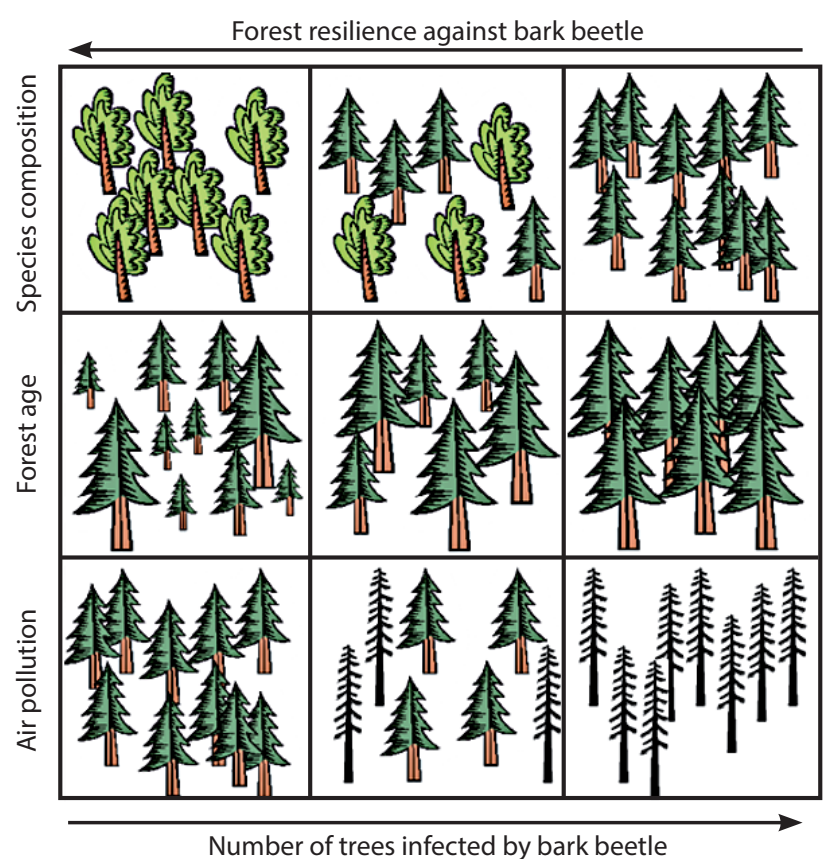

Fig. 5 Forest resilience against attacks by bark beetles associated with different types of weakening: species structure, age structure and air pollution. 
tion of the annual precipitation. These changes are most obvious in winter, the period when rainfall is lowest. The highest temperature increase occurred in April $\left(3-4{ }^{\circ} \mathrm{C}\right)$ and this strongly affects snow melt. Snow cover melts about 3-5 weeks earlier now than 40 years previously, which also affects the water regime in summer.

The fact that the spontaneous forest regeneration cannot be allowed to occur in the whole NP, especially in the boundary between the core, unmanaged zones and economic forests. A convenient solution to this problem is in a proper zonation of the unmanaged forests (core zones) and economic forests. This would require replacing the current 135 small and isolated zones by fewer and larger core zones that in total have a shorter peripheral border, i.e. a decrease in the area where it will be neccessary to fell trees attacked by bark beetles. It is important to realize that the current problem we face is not a choice between green or dead forest but do we want clearcuts or dead regenerating forest. Pokorný et al. (2016) mention that there are a number of negative effects associated with dead forest but the negative effects associated with clear-cut areas are much more serious. Both the cooling effect of green forest and the decrease in evapotranspiration when green forest dies occur, but this is also true for clear-cut areas to an even greater extent. However, vegetation loss does not necessarilly mean an increase in water run-off, which is supported by the long-term measurments recorded for Modravský potok (Hruška et al. 2016) and upper Vydra and Große Ohe (Bernstein et al. 2015).

Moreover, bark beetles could be used as a natural means of restoring more natural mountainous forests (Jonášová and Prach 2004; Hais et al. 2009). Hais et al. (2009) studied several plots in the Šumava NP that were managed in two different ways after bark beetle attack: 1. Forest left uncut and 2. forest completely felled. They recorded a significant difference in the spectral reflection from the vegetation in aerial photographs taken from 1985 to 2007. The reflection from plots that were not clear cut was the most similar to that of normal healthy forest and that from the clear cut plots deviated significantly from the normal state.

In the case of national parks, natural processes should be promoted rather than clear cutting followed by the planting of trees, particularly in the core zones of the NP. Economics should not endanger the protection of nature and the water regime.

\section{Acknowledgements}

This research was supported by the MSMT within National Sustainability Program I (NPU I), grant number LO1415.

\section{REFERENCES}

Bečka P, Beudert B (2016) Kůrovec a voda. Jak bezzásahovost ovlivňuje vodní režim na Šumavě. Šumava, jaro: 16-17.

Bernstein J, Bässler C, Zimmermann L, Langhammer J, Beudert B (2015) Changes in runoff in two neighbouring catchments in the Bohemian Forest related to climate and land cover changes. J Hydrol Hydromech 63: 342-352.

Beudert B, Bässler C, Thorn S, Noss R, Schröder B, Dieffenbach-Fries H, Foullois N, Müller J (2015) Bark beetles increase biodiversity while maintaining drinking water quality. Conserv Lett 8: 272-281.

Gutierrez V (2016) Management lesů a jeho význam pro vodu a klimatizaci krajiny. Vodní hospodářství 2: 24-25.

Hais M, Brom J, Procházka J, Pokorný J (2006) Effect of water drainage on the forest microclimate; case study of two small catchments in the Šumava mountains. Ekológia Bratislava 25: $18-26$.

Hais M, Jonášová M, Langhammer J, Kučera T (2009) Comparison of two types of forest disturbance using multitemporal Landsat TM/ETM+ imagery and field vegetation data. Remote Sens Environ 113: 835-845.

Hais M, Kučera T (2008) Surface temperature change of spruce forest as a result of bark beetle attack: remote sensing and GIS approach. Eur J Forest Res 127: 327-336.

Hais M, Pokorný J (2004): Změny teplotně-vlhkostních parametrů krajinného krytu jako důsledek rozpadu horských smrčin. Aktuality šumavského výzkumu 2: 49-55.

Hruška J, Lamačová A, Chuman T (2016) Bezzásahový režim nemá zásadní vliv na hydrologii šumavských povodí. Ochrana prírody: $35-38$.

Hubený P, Č́žková P (2016) Šumavské lesy pod lupou. Správa Národního parku Šumava, Vimperk.

Jonášová M, Prach K (2004) Central-Europen mountain spruce forests: regeneration of tree species after a bark beetle outbreak. Ecol Eng 23: 15-27.

Kindlmann P, Křenová Z (2016) Biodiversity: Protect Czech park from development. Nature 531: 448.

Kindlmann P, Matějka K, Doležal P (2012) Lesy Šumavy, lýkožrout a ochrana prrírody. Karolinum, Praha.

Makarieva A, Gorshkov V (2007) Biotic pump of atmospheric moisture as driver of the hydrological cycle on land. Hydrol Earth Syst Sci 11: 1013-1033.

Pokorný J (2011) Co dokáže strom. In: Kleczek J (ed) Voda ve vesmíru, na zemi, v životě a v kultuře. Radioservis Praha, pp. 429-431.

Pokorný J, Hesslerová P (2011) Odlesňování a klima. Klimatické změny v Mau Forest v západní Keni. Vesmír 9010): 573-578.

Pokorný J, Hesslerová P, Jirka V (2011) Změny povrchové teploty les jako následek ztráty vody a poklesu evapotranspirace. Lesnická práce 12: 26/819-29/822.

Tesař M, Šír M, Zelenková E (2004) Vliv vegetace na vodní a teplotní režim tří povodí ve vrcholovém pásmu Šumavy. Aktuality šumavského výzkumu 2: 84-88.

Vicena I (2004) Př́roda je více než kůrovec. Lesnická práce 9.

Zielonka T, Piątek G (2004) The herb and dwarf shrubs colonization of decaying logs in subalpine forest in the Polish Tatra Mountains. Plant Ecol 172: 63-72. 